\title{
Microstructure of Harzer-Like Cheese
}

\section{Hesham A. Ismail ${ }^{1}$ and ${ }^{*}$ Adel A. Tammam ${ }^{2}$}

${ }^{1}$ Dairy Science Department, Faculty of Agriculture New Valley, Assiut University.

${ }^{2}$ Dairy Science Department, Faculty of Agriculture, Assiut University, Egypt.

*E-mail: aat@aun.edu.eg

\begin{abstract}
:
Harzer-like cheese was made from cow's, buffalo's, reconstituted milk and skim milk retentate. Submicroscopic structure and sensory evaluation during ripening were studied. The obtained results show that in the early stage of ripening period, the protein network of cow's skim milk cheese appeared as a large casein fibers, while in buffalo's milk, cheese was less dense, with open network, casein micelles in reconstituted milk cheese were coalesce and retentate cheese was more compact than other cheeses. After 8 weeks of the ripening period, the extent of hydrolysis of casein in cheese, casein micelle cow's skim milk cheese fused, formed homogeneous structure. The microstructure of buffalo's milk cheese was compact with few gaps. Reconstituted milk cheese casein particles counseled together in sheets but retentate cheese had coarser protein network. Finally the disintegration of the casein occurs much faster in cow's skim milk cheese, with more extensions of aggregated casein micelle than in the other cheeses, and was of good sensory quality.
\end{abstract}

Key words: Harzer-like cheese; milk types; microstructure and sensory evaluation.

Received on: $24 / 11 / 2015$

Referees: Prof. Aly I. Hassan
Accepted for publication on: 13/12/2015

Prof. Taha A. Nasseb 


\section{Introduction:}

Harzer-cheese is non-rennet variety (acid curd cheese) made from skim milk, relying on acid production by lactic acid bacteria for milk coagulation, has a soft waxy body with no evidence of crudeness at the center. The surface of smear ripened cheeses, like Tilsit, Limburg, Romadur, Chaumes, and acid curd cheese (Harzer) is covered by a layer of yeasts and bacterial flora (Brennan et al., 2002). Enzymes produced by the bacterial flora, grow on the surface of smear cheeses play essential roles in the flavour development during cheese ripening (Curtin et al., 2002). The proteolytic action of microorganisms leads to disruption of cheese protein structure during ripening (Omar, 2012).

Microstructure analysis plays an important role in the quality evaluation of dairy products: better quality usually brings higher revenues and consumer satisfaction. Consumer acceptance of a cheese product depends directly on its appearance, flavour and texture which are in turn originated by a thorough combination of microbiological, biochemical and technological parameters, which affect microstructure directly or indirectly (Impoco et al., 2012 and Ismail, 2013).

Texture is intrinsically related to the arrangement of various chemical components within distinct microand macrostructure levels, e.g., protein networks or fat fractions; it is the external manifestation of such structures that eventually determines the uniqueness and distinctive character of a cheese product. However, cheeses are particularly complex systems, so full and meaningful assessment of the effects of microstructure (and texture) upon flavour and appearance is still incipient (Pereira et al., 2009). The changes of protein and the degree of proteolysis in cheese, which is considered a measure of ripening can be determined also by physical methods such as electron microscopy.

Scanning electron microscope (SEM) helped elucidate how total or partial substitution of regular milk fat produces cheeses with different microstructures and inherently distinct textural characteristics (LobatoCalleros et al., 2007). The microstructure of low or free fat cheese was completely different than that of the full fat cheese, with the number of milk fat globules decreasing and the protein matrix becoming more compact. This probably explained the harder texture observed in low or free fat cheese, even though it was significantly higher in moisture content (Bryannt et al., 1995). As fat content decreases, the protein matrix becomes more compact and the cheese texture is more chewy (Zalazar et al., 2002). However, decreasing the fat percentage often leads to textural drawbacks, viz. a hard body with poor meltability and stretchability, as well as a rubbery texture. The flavour, colour and mouthfeel of cheese will also be adversely affected, since a few compounds dissolve preferentially in fat, although a higher smoothness may also be imparted to the cheese matrix (Mistry, 2001).

The development of microstructure of various types of cheese during ripening was characterized by a vary- 
ing degree of disintegration of casein micelles resulting in a penetration of whey into the disintegrated casein mass (Omar and Buchheim, 1983).

The main objectives of the present work was undertaken to study the changes in the microstructure and the sensory evaluation of Harzer-like cheese made from different skim milk types under local conditions during ripening.

\section{Materials and Methods:}

Fresh and cooled raw cow and buffalo's milk were obtained from the herd of Assiut Governorate farm. Retentate resulting from ultrafiltration $\left(\times_{3}\right)$ of raw cow's skim milk was carried out at Animal Production Research Institute, using carbosep UF unit Cairo, Egypt, and skim milk powder was purchased from the local market and reconstituted in water at the ratio of 1:8. Pure fine of cooking salt $(\mathrm{NaCl})$ produced by Tag El Melouk Food Industries was used in manufacturing of the investigated cheese. Yoghurt starter of mixed Streptococcus thermophilius and Lactobacillus delbrueckii subsp. bulgaricus were obtained from Chr. Hansens laboratory, (Copenhagen, Denmark). Yoghurt starter was propagated separately in sterilized reconstituted skim milk at the optimum temperature (Str. thermophilius at $45^{\circ} \mathrm{C} \pm 1{ }^{\circ} \mathrm{C}$ and $L$. delbrueckii subsp. bulgaricus at $38^{\circ} \mathrm{C}$ $\pm 1^{\circ} \mathrm{C}$ ) for $16-18$ hours, and mixed at rate of $1: 1$ just before adding to cheese milk. Smear of isolated microorganisms and preparation from ripened Limburger cheese produced during the preliminary experiments were carried out as described by Ismail (2013).
Saline suspension of smear microorganisms was prepared immediately before cheese manufacture as follows: Six-5-mm thickness surface slices from smear Limburger cheese were placed in sterile blender jar containing $500 \mathrm{ml}$ of $0.85 \% \mathrm{NaCl}$ solution and homogenized for ca. $1 \mathrm{~min}$ at high speed (Ryser and Marth, 1989).

Four Harzer-like cheeses made from skim milk cow's, buffalo's, and reconstituted milk, and skim milk retentate were made by using the method described by Valdés-Stauber et al. (1997). Skim milk samples were heated to $73^{\circ} \mathrm{C} / 15 \mathrm{Sec}$. and cooled to $30^{\circ} \mathrm{C}$, then inoculated with $1 \%$ yoghurt starter, and left at room temperature $\left(25-30^{\circ} \mathrm{C}\right)$, until complete coagulation. The resultant curd of all treatments were cut and ladled in quarter stainless steel molds at room temperature $\left(25-30^{\circ} \mathrm{C}\right)$. The molds were inverted after shaping for $24 \mathrm{hr}$. Cheeses blocks were immersed in pasteurized brine $(10 \% \mathrm{NaCl})$ within 1\% saline suspension (contain smear microorganisms) overnight at room temperature $\left(25-30^{\circ} \mathrm{C}\right)$. Cheeses were ripened on shelves at $15-18^{\circ} \mathrm{C}$ and a $85-90 \%$ relative humidity $(\mathrm{RH})$ for 8 weeks. During ripening, the cheese was sprayed weekly with saline suspension of flora to close the surface openings and to help in distributing the ripening microorganisms all over the surface. Cheese samples were taken to SEM and sensory evaluation when fresh, and after 4 and 8 weeks of ripening.

The Electron Microscopic examination was performed in the Egyptian Mineral Resources Authority Central Laboratories Sector according to Karami et al. (2009). Har- 
zer-like cheeses were examined by using SEM (FEI Company, Netherlands) Model Quanta 250 FEG (Field Emission Gun) attached with EDX Unit (Energy Dispersive X-ray Analyses), with accelerating voltage 10 K.V. During SEM analysis, samples were freeze-fractured in liquid nitrogen to approximately $1-\mathrm{mm}$ pieces and these pieces were then mounted on aluminum stubs with silver paint, dried to critical point and coated with gold for $300 \mathrm{~A}^{\circ}$ in a Sputter- Coater (SCD 005 Sputter Coater) and scanned under low vacuum condition with pressure chambers 60 pa.

The sensory evaluation of cheese was assessed by 15 panelists of staff members and some other consumers, for flavor (50 points), body and texture (35 points), and appearance (15 points) using the scores sheet according to Scott (1981).

Statistical analysis were performed using statistical package for Social Studies (SPSS) software (SPSS, 1999) at $\mathrm{P}<0.05$. General Linear Models were used to estimate of proteolysis and sensory characteristics during ripening cheese. Differences between means were determined by Duncan's multiple range test at a level of 0.05 probability (Steel \& Torrie, 1980).
Results and Discussion:

In the manufacture of Harzerlike cheese being coagulated by decreasing its $\mathrm{pH}$ by lactic acid starter bacteria. Lactic acid bacteria have been claimed to contribute to cheese microstructure, their role in proteolysis, and their capability to improve cheese body and texture (Hassan et al., 2004).

Fig. (1) shows that fresh cheeses are composed of distributed casein micelles in the form of clusters and chains similar to that observed by Abd El-Salam and Omar (1985) in Kariesh cheese and Omar and Hosaja (1986) in Twarog cheese. Scanning electron microscope (SEM) image microstructure of Harzer-like cheese made from cow's skim milk, appeared as large masses of dense filaments segregated from the protein network (Hassan et al., 2003). The protein network of buffalo's skim milk cheese was less dense, more open, and with more void spaces than in whey of the cow's skim milk cheese, as consequence of smaller fused casein micelles aggregates. Lucey et al. (1998) and Modler \& Kalab (1983) observed in yoghurt made from skim milk and stabilized with gelatin that casein micelles linked in long chains rather than in casein micelles aggregates. As seen in reconstituted skim milk cheese, the casein micelles aggregate and coalesce with structure composed. 

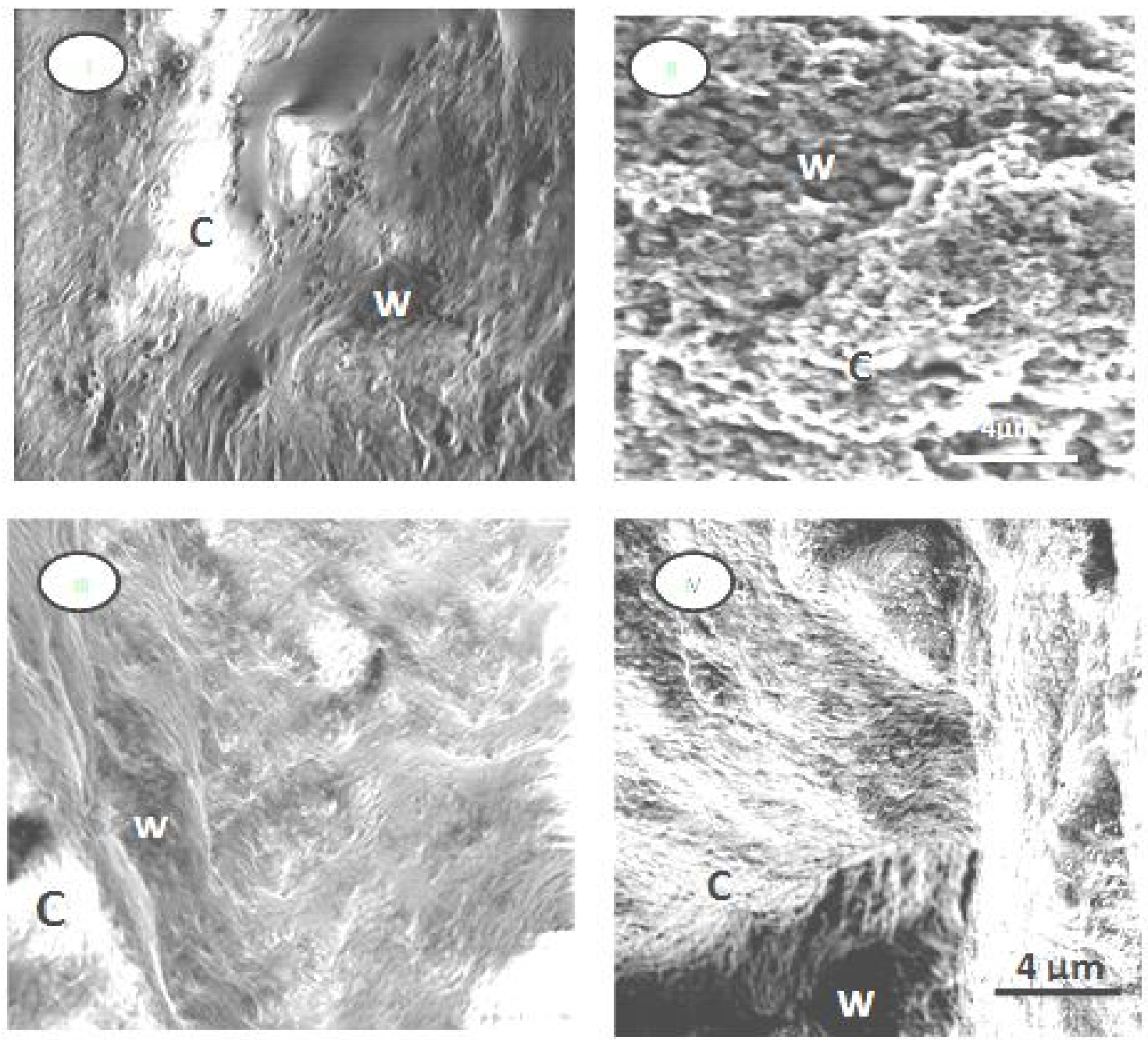

Fig. (1): SEM micrographs of fresh Harzer-like cheese made from different skim milk types; (I): Cow's , (II):Buffalo's, (III): Reconstituted, (IV): Retentate.

\section{(C): Casein, (W): whey Bar: $4 \mu \mathrm{m}$}

The microstructure of retentate cheese was more compact, consistent with the increased hardness, and casein micelles were denser with smaller pores. This dense network might arise due to the increased aggregation of casein micelles (Ong et al., 2013). The microstructure of the cheese changed during ripening of 4 weeks, the gel network consisted of particles considerably larger than the network of fresh cheese, indicating an extensive aggregation of protein. Also, the protein mass disintegrates into subunits fused with extensive in- teraction inside the protein matrix. As soon as the protein aggregates, its loses their spherical shape suggesting extensive fusion (Abd El-Salam and Omar, 1985).

The protein matrix of cow's skim milk cheese (Fig. 2) shows homogensity in the structure, the relatively small subunits aggregated together through the aqueous phase, consistency of nearly continuous fibers mass of single casein particles. Buffalo's skim milk cheese showed a relatively open, loose structure, with the casein micelles linked in chains, 
with a large number of interspaced voids of varying dimensions. Some of the solubilized molecules may integrate into the casein micelles network, and be responsible for structure openness. Granular structures attributed to deposited casein micelles and casein chains can be seen on the surface (Dinkçi et al., 2011). Thus re-
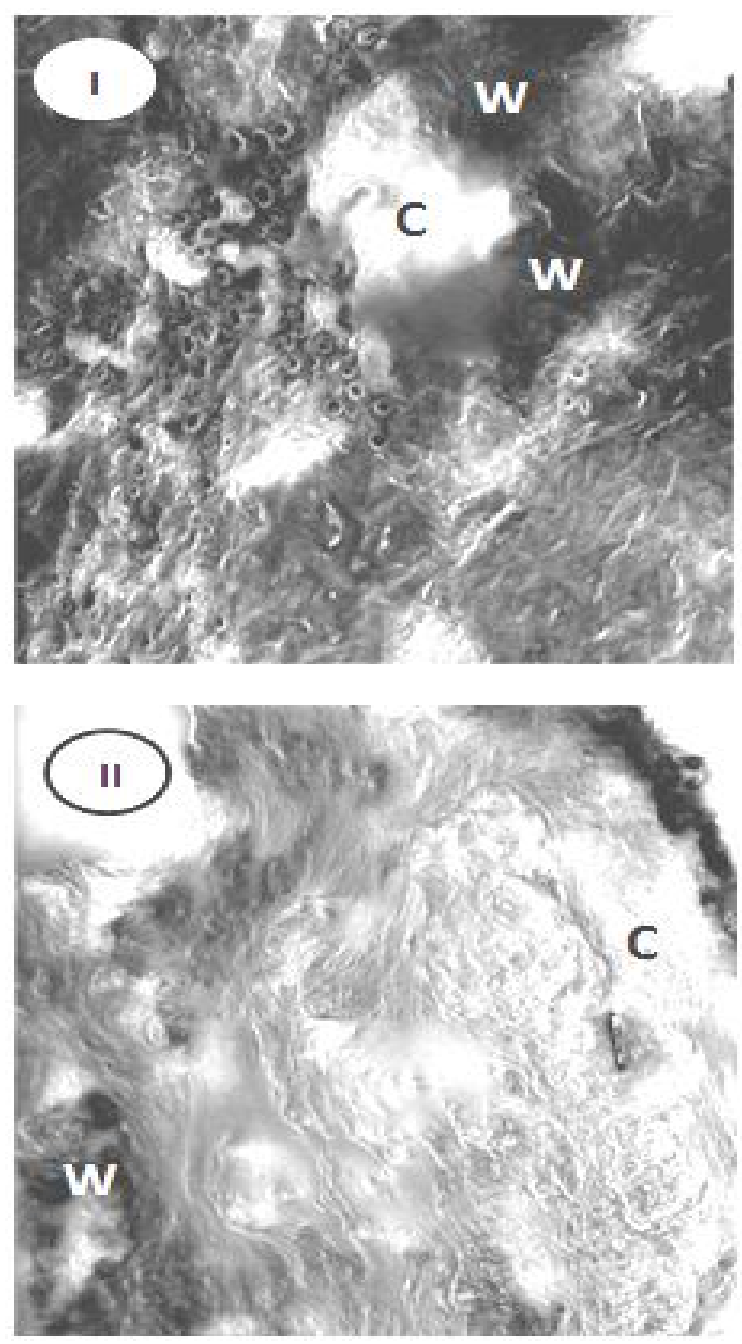

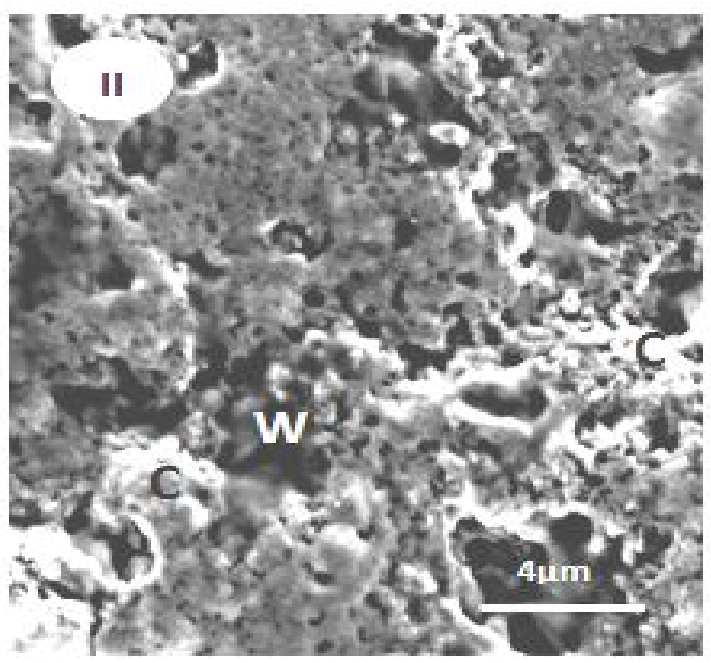

constituted skim milk cheese exhibited a protein network formed by predominantly casein micelles layers, but some of them were fused into aggregates. The disintegration of the casein occurs much faster in cow's skim milk cheese, with more extensions of aggregated casein micelles, than in the other cheeses.

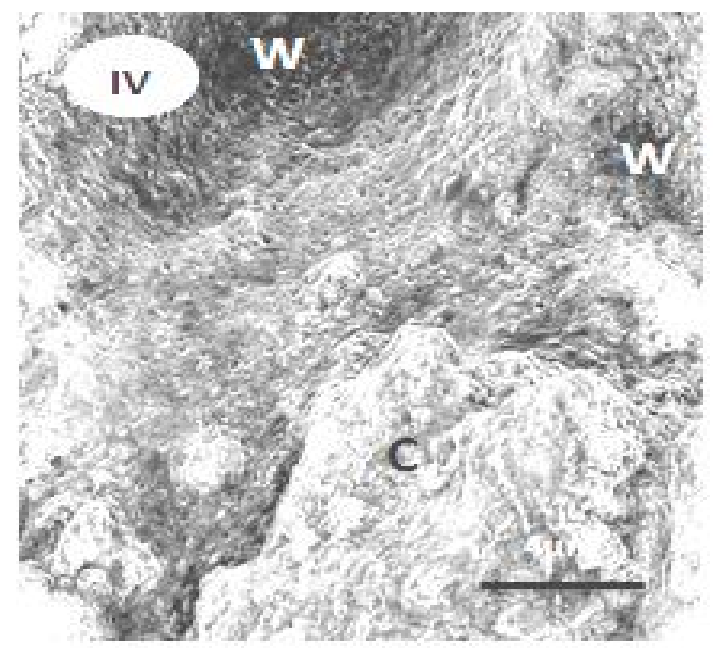

Fig. (2): SEM micrographs of four weeks age Harzer-like cheese made from different skim milk types; (I): Cow's, (II):Buffalo's, (III):Reconstituted, (IV): Retentate.

(C): Casein, (W): whey Bar: $4 \mu \mathrm{m}$

The physical structure of Harzer-like cheese were changed during ripening and after 8 weeks of storage indicate that the extent of hydrolysis of casein in cheese (Fig. 3). Disinte- 
gates with homogeneous structure where the whey could be seen within the casein matrix, as reported by Knoop and Buchheim (1980). Buffalo's skim milk contains small pores and had compact appearance. In cheese made from reconstituted milk, casein micelles collected together in sheets with more curd junction. The cheese matrix appears in closely packed lumps, finally granulated mass, forming a network with closely visible gaps between the clusters, structural information or orientation, whereas casein having a loose randomly coiled structure. Thus the microscopic structure of cheese protein changes during ripening period parallel to the chemical degradation. UF skim milk cheese had a coarser protein network, and a reduced volume of whey, compared to cheese made using cow's skim milk. Final texture of the cheese tended to be granular and hard and the fusion of casein was lower.
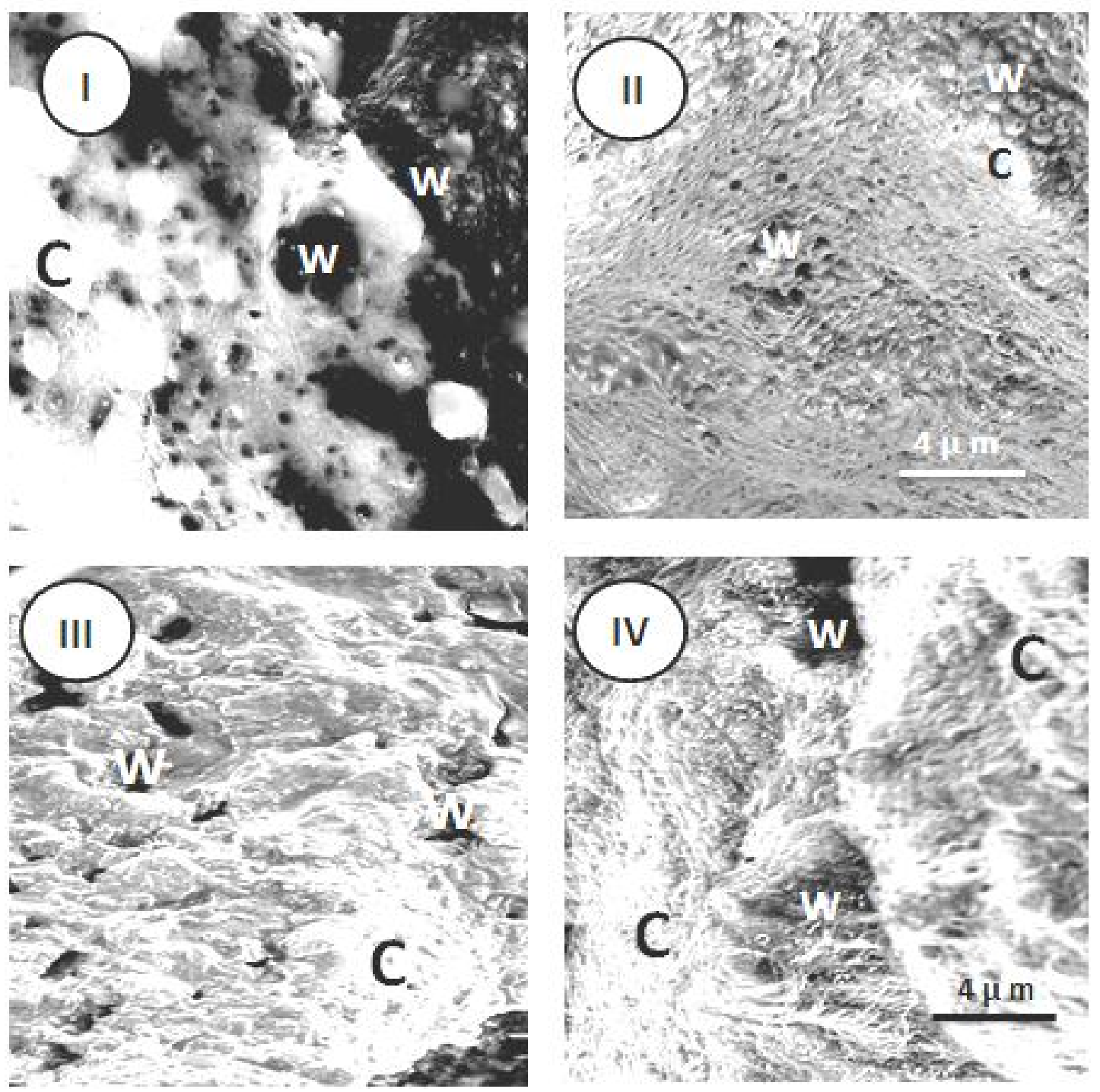

Fig. (3): SEM micrographs of eight weeks age Harzer-like cheese made from different skim milk types; (I): Cow's, (II):Buffalo's, (III):Reconsituted, (IV): Retentate

(C): Casein, (W): whey Bar: $4 \mu \mathrm{m}$. 


\section{Sensory evaluation:}

Lactic acid bacteria metabolize the lactic acid to produced $\mathrm{CO} 2$ and $\mathrm{H} 2 \mathrm{O}$, and deaminate amino acids, producing $\mathrm{NH} 3$, both of which results in an increase in the $\mathrm{pH}$ of the cheese. The increase in $\mathrm{pH}$ modifies the rheological properties of the cheese, resulting in a soft body, which is typical of this type of cheese (Eliskases-Lechner and Ginzinger, 1995). Proteolysis is a major factor in the development of the texture and organoleptic properties of bacterial surface ripened soft cheese (McSweeney and Fox, 1997). B. linens is a major micro-organism in the smear of sur- face- ripened cheeses. Its enzymes, especially proteolytic and lipolytic ones, and biochemical characteristics influence the ripening and final characteristics of smear surface-ripened cheeses (Rattray and Fox, 1999). The results of the sensory evaluation assessment of cheese quality when fresh, and after four and eight weeks of ripening (Table 1). The good textural quality of acid curd Harzer-like cheeses was observed, as smooth and elastic in cow's skim and reconstituted milk cheese respectively. This probably due to their high moisture content than that in retentate and buffalo's cheeses.

Table (1): Sensory evaluation of Harzer-like cheese made from different types of skim milk.

\begin{tabular}{|c|c|c|c|c|c|}
\hline \multirow[b]{2}{*}{$\begin{array}{c}\text { Cheese } \\
\text { age }\end{array}$} & \multirow[b]{2}{*}{$\begin{array}{c}\text { Organoleptic } \\
\text { properties }\end{array}$} & \multicolumn{4}{|c|}{ Cheeses made from } \\
\hline & & $\begin{array}{c}\text { Cow's skim } \\
\text { milk }\end{array}$ & $\begin{array}{c}\text { Buffalo's } \\
\text { skim Milk }\end{array}$ & $\begin{array}{l}\text { Reconstituted } \\
\text { skim milk }\end{array}$ & $\begin{array}{c}\text { Cow's skim } \\
\text { milk } \\
\text { retentate } \\
\end{array}$ \\
\hline \multirow{4}{*}{ 预 } & Appearance (15) & $6 \pm 0.58^{\mathrm{a}}$ & $6.33 \pm 0.33^{\mathrm{a}}$ & $6.67 \pm 0.67^{\mathrm{a}}$ & $5.67 \pm 0.33^{\mathrm{a}}$ \\
\hline & Body \& texture (35) & $12 \pm 0.58^{b}$ & $15 \pm .58^{\mathrm{a}}$ & $13.67 \pm 0.88^{\mathrm{ab}}$ & $12.67 \pm 0.88^{\mathrm{ab}}$ \\
\hline & Flavour (50) & $22 \pm 0.57^{\mathrm{a}}$ & $21.17 \pm 0.44^{\mathrm{a}}$ & $21 \pm 0.58^{\mathrm{a}}$ & $20.67 \pm 0.67^{\mathrm{a}}$ \\
\hline & Total (100) & $40 \pm 1.00^{\mathrm{a}}$ & $42.5 \pm 0.50^{\mathrm{a}}$ & $41.3 \pm 0.88^{\mathrm{a}}$ & $39 \pm 1.53^{\mathrm{a}}$ \\
\hline \multirow{4}{*}{ 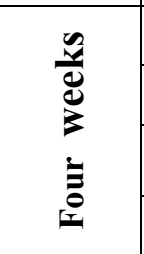 } & Appearance (15) & $12 \pm 0.58^{\mathrm{a}}$ & $10 \pm 0.58^{b}$ & $11 \pm 0.58^{\mathrm{ab}}$ & $8 \pm .58^{c}$ \\
\hline & Body \& texture (35) & $26 \pm 0.88^{\mathrm{a}}$ & $25 \pm 0.58^{a}$ & $25 \pm 0.58 \mathrm{a}$ & $21 \pm 1.00^{b}$ \\
\hline & Flavour (50) & $42 \pm 1.16^{\mathrm{a}}$ & $39 \pm 0.58^{b}$ & $39.33 \pm 0.67 \mathrm{ab}$ & $31.33 \pm 0.88^{\mathrm{c}}$ \\
\hline & Total (100) & $80.3 \pm 1.76^{\mathrm{a}}$ & $74 \pm 1.53^{b}$ & $75.3 \pm 1.20^{b}$ & $60.3 \pm 0.88^{c}$ \\
\hline \multirow{4}{*}{ 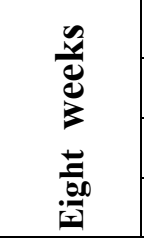 } & Appearance (15) & $12.83 \pm 0.73^{\mathrm{a}}$ & $12 \pm 0.58^{\mathrm{a}}$ & $13 \pm .00^{\mathrm{a}}$ & $10.33 \pm 0.33^{b}$ \\
\hline & Body \& texture (35) & $32 \pm 0.58^{a}$ & $29 \pm 0.58^{b}$ & $30.83 \pm 0.60^{a b}$ & $24 \pm 1.16^{\mathrm{c}}$ \\
\hline & Flavour (50) & $45.33 \pm 0.33^{\mathrm{a}}$ & $39.67 \pm 0.88^{b}$ & $42 \pm 1.00^{b}$ & $35 \pm 0.58^{\mathrm{c}}$ \\
\hline & Total (100) & $90.2 \pm 0.44^{\mathrm{a}}$ & $80.7 \pm 0.88^{c}$ & $85.8 \pm 1.48^{b}$ & $69.3 \pm 1.76^{\mathrm{d}}$ \\
\hline
\end{tabular}


Buffalo's cheese had opening texture but in retentate cheese appearance rough and coarser texture. The appearance scores for the cheese made from cow's skim milk was significantly $(\mathrm{P}<0.05)$ higher than those of the other cheese types. Moreover, no significantly $(\mathrm{P}>0.05)$ differences in score were observed between the cheeses made from buffalo's milk and retentate. The texture of cow's skim milk was more uniform, most likely due to continuing proteolysis of the casein matrix. The ripening of acid curd like cheese was visualized by the conversion of the white to a yellow-red cheese from the surface during ripening.

\section{Conclusions:}

Each cheese variety has its characteristic structural features, which reflect the biochemical changes in the cheese. In this study, casein micelles in Harzer-like cheese made from cow's skim milk tightly fused, from large aggregates with homogeneous structure, where the whey can be seen within the casein matrix. Scanning electron micrographs showed that the protein matrix of Harzer-like cheese made from buffalo's milk was of differing structures, which in general terms were more open. The fusion of casein was lower in skim retentate cheese, which had a loose structure. Generally, microstructures of Harzer-like cheese made from cow's skim milk forming large and extensively fused casein micelles than that in other cheeses. Change in structure observed for all cheese samples regardless of protein content and rate proteolysis. This difference may influence the flavour perception and texture of the cheese.

\section{References:}

Abd El-Salam, M.H. and Omar, M.M. (1985). Microstructure of Kariesh cheese. J. Dairy Res. 52:299-301.

Brennan, N. M, Ward, A. C., Beresford, T. P., Fox, P. F., Goodfellow, M. and Cogan, T.M. (2002). Biodiversity of the bacterial flora on the surface of a smear cheese. Appl. and Environ. Microbiol. 68: 820-830.

Bryannt, A. Z., Ustunol, Z. and Steff, J. (1995). Texture of cheddar cheese as influenced by fat reduction. J. Food Sci. 62:901907.

Curtin, A.C., Gobbetti, M., and McSweeney, P.L.H. (2002). Eptidolytic, esterolytic and amino acid catabolic activities of selected bacterial strains from the surface of smear cheese. Int. J. Food Microbi. 76 : 231-240.

Dinkçi, N., Kesenkaş, H., Seçkin, A.K., Kınık, Ö. and Gönç, S. (2011). Influence of a vegetable fat blend on the texture, microstructure and sensory properties of kashar cheese. Grasas Y Aceites 62: 275-283.

Eliskases-Lechner, F. and Ginzinger, W. (1995). The yeast flora of surface-ripened cheese. Milchwissenschaft 50: 458-462.

Hassan, A.N., Frank, J.F. and ElSoda, M. (2003). Observation of bacterial exopolysaccharide in dairy products using cryoscanning electron microscopy. Int. Dairy J. 13:755-762. 
Hassan, A.N., Correding, M., Frank, F. and El-Soda, M. (2004). Microstructure and rheology of an acid-coagulated cheese (Karish) made with and exopolysaccharide-producing Streptococcus thermophilus strain and it exopolysaccharide nonproducing genetic variant. J. Dairy Res. 71: 116-124.

Impoco, G., Fucà, N., Tuminello, L. and Licitra, G. (2012). Quantitative image analysis of food microstructure. Current Microscopy Contributions to Advances in Science and Technology: 903-911.

Ismail A. H. (2013). Studies on bacterial surface ripening cheese. $\mathrm{Ph}$.

D. Thesis, Faculty of Agric, Zagazig Univ., Egypt.

Karami, M., Ehsani, M.R., Mousavi, S.M., Rezaei, K. and, Safari, M. (2009). Changes in the rheological properties of Iranian UF-Feta cheese during ripening. Food Chem. 112: 539-544.

Knoop, A.M. and Buchheim, W. (1980). Die unterschiedliche Entwicklung der substruktur bei der Reifung von Harzer, Tilsiter-und Camembert-käse. Milchwissenschaft 35: 482-488.

Lobato-Calleros, C., ReyesHernandez, J., Beristain, I.C., Hornelas- Uribe, Y., SanchezGarcia, J. E. and Vernon-Carter, E. J. (2007). Microstructure and texture of white fresh cheese made with canola oil and whey protein concentrate in partial or total replacement of milk fat. Food Res. Int. 40: 529-537.

Lucey, J. A., Munro, P. A. and Singh, H. (1998). Rheological proper- ties and microstructure of acid milk gels as affected by fat content and heat treatment. J. Food Sci. 63:660-664.

McSweeney, P.L.H., and Fox, P. F. (1997). Chemical methods for the characterization of proteolysis in cheese during ripening. Lait 77:41-70.

Mistry, V. V. (2001). Low fat cheese technology. International Dairy Journal 11:413-422.

Modler, H.W. and Kalab, M. (1983). Microstructure of yoghurt stabilized with milk proteins. J. Dairy Sci. 66: 430-437.

Omar, M.M. (2012). Microstructure of semi hard type cheese made from reconstituted whole milk powder. Egyptian J. Dairy Sci. 40:45-57.

Omar, M.M., and Buchheim, W. (1983). Composition and microstructure of soft brine cheese made from instant whole milk powder. Food Microstructure 2: 43-50.

Omar, M.M. and Hosaja, M. (1986). Microstructure and chemical changes in Twarog cheese made from ultrafiltrated milk and from lactose hydrolyzed milk. Food chemistry 22: 147-163.

Ong, L., Dagastine, R. R., Kentish, S. E. and Gras, S. L. (2013). Microstructure and composition of full fat cheddar cheese made with ultrafiltered milk retentate. Foods 2: 310-331.

Pereira, C.I., Gomes, A.M.P. and Malcata, F. X. (2009). Microstructure of cheese: Processing, technological and microbiological considerations. Trends in 
Food Science \& Technology 20:213-219.

Rattray, F.P., and Fox, P.F. (1999). Aspects of enzymology and biochemical properties of $\mathrm{Bre}$ vibacterium linens relevant to cheese ripening: a review. J. Dairy Sci. 82: 891-909.

Ryser, E.T. and Marth, E.H. (1989). Behavior of Listeria monocytogenes during manufacture and ripening of Brick cheese. J. Dairy Sci. 72:838-853.

Scott, R. (1981). Cheese making practice. Applied Sci. Publisher Ltd. London.

SPSS. (1999). SPSS for Windows Release 10.0. Standard Version Copyright SPSS Inc. 198.
Steel, R.G.D. and Torrie, J.H. (1980). Principles and Procedures of Statistics. New York, NY. McGraw-Hill Book Co., Inc.

Valdés-Stauber, N., Scherer, S. and Seiler, H. (1997). Identification of yeasts and coryneform bacteria from the surface microflora of Brick cheese. Int. Food Microbiol. 34:115-129.

Zalazar, C. A., Zalazar, C.S., Bernal, S., Bertola, N., Bevilacqua, A. and Zraitzky, N. (2002). Effect of moisture level and fat replacer on physico-chemical, rheological and sensory properties of low fat soft cheeses. Int. Dairy J. 12: 45-50. 


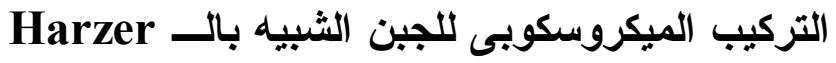

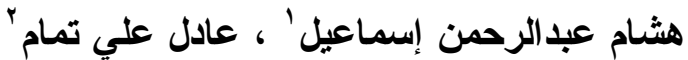

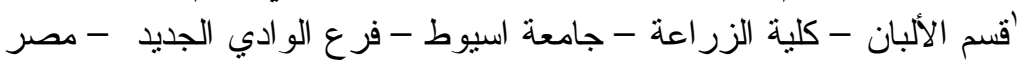

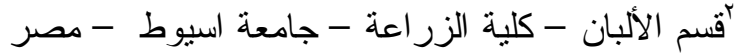

(الملخص:

تتميز الجبن Harzer بقو ام طرى شمعى غير عجينى من الداخل ، يساهم فــى صــفاتها

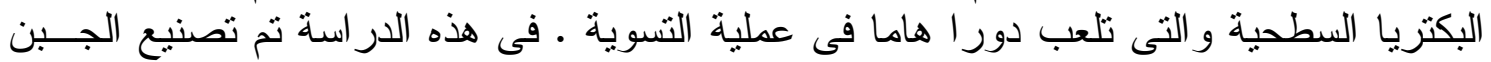

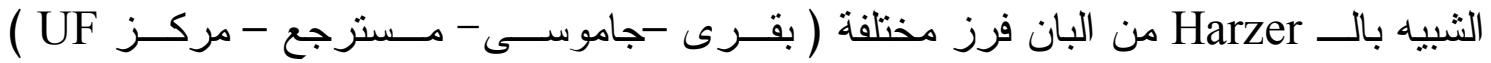

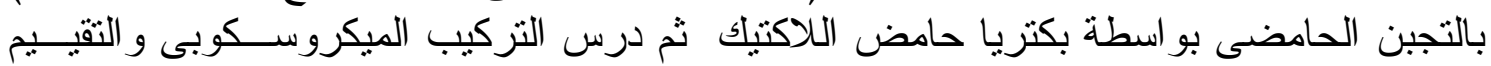

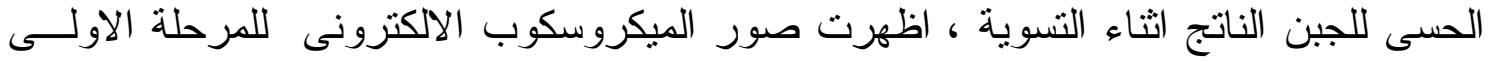

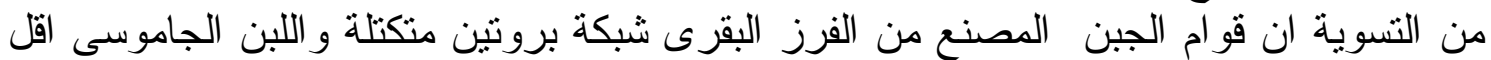

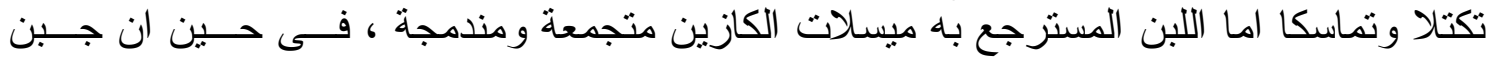
مركز الترشيح الفائق (UF) اكثر التحاما وصلابنة.

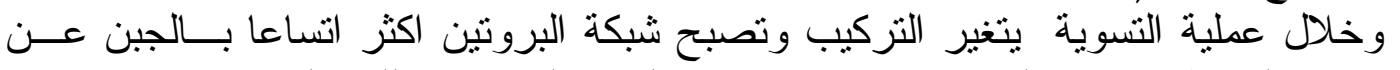

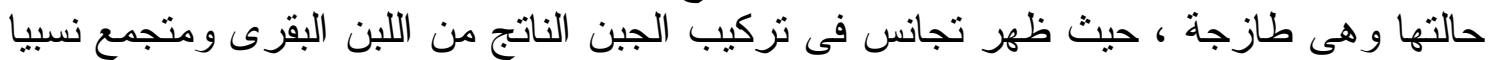

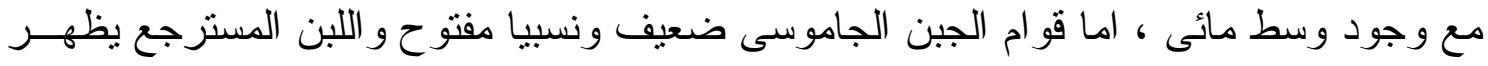

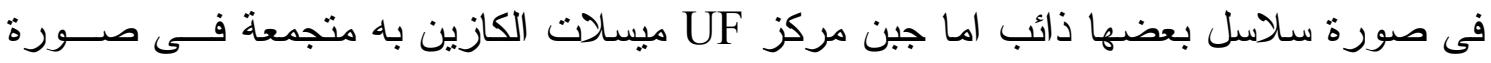
عناقيد

مع استمر ار عملية التسوية حتي الأسبوع الثامن يزداد تحلل الكازين بشدة ويلاحظ بالجبن

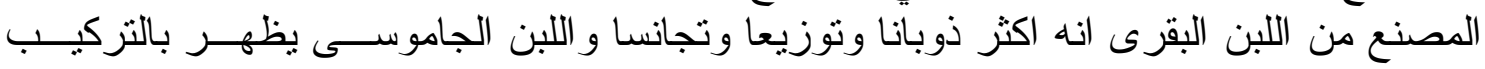

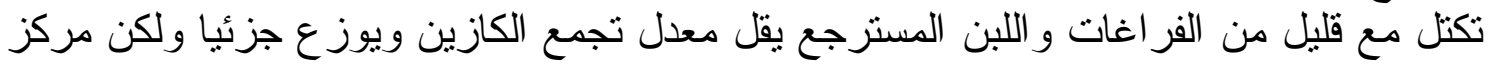

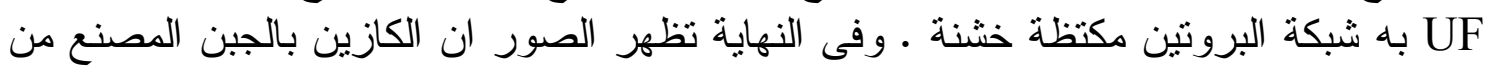

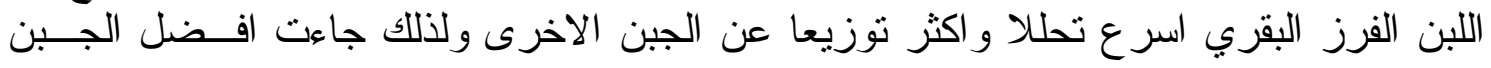

